\title{
The flex-fuel technology building process in Brazil: An analysis from the perspective of business platform
}

\author{
Daniel Leite Mesquita* and Joel Yutaka Sugano \\ Department of Administration and Economy, Federal University of Lavras, Brazil. \\ Accepted 17 May, 2011
}

\begin{abstract}
The conceptual perspective of "business platform" intent to demonstrate that in the current situation, industries can jointly establish innovations through formal exchanges of expertise between a "leader firm and its complementary." The research had qualitative and exploratory character, using grounded theory techniques and thematic content analysis of five in-depth interviews made to automakers and suppliers of flex-fuel technology. The flex-fuel technology as a "business platform", presented the following results: there were modifications in the architecture of the engine flex-fuel-related components; the technology emerged from a strong relationship of exchange of expertise among the "Modules "(the systemists and the automakers). The interviewees reported the existence of co-design in the development and application part of this technology. The power of the automakers in the "architecture" of the flex-fuel platform is also highlighted by the leadership in the chain of the automotive industry. Finally, it was elaborated a model of "flex-fuel business platform from the concepts drawn from the interviews. It was concluded that the flex-fuel platform is led by automakers that hold the core architecture of the engine. Innovations of high aggregated value, as the case of flexfuel, require partnerships and standardization with "complementary" (large and small suppliers).
\end{abstract}

Key words: Flex-fuel technology, business platform, automotive industry.

\section{INTRODUCTION}

The automobile industry has changed the notion of society as how to produce goods. Moving from the American model of mass production to the Japanese model of lean production, the technological impacts in that industry were reflected in an increasingly complexity in the car's architecture that since the 80's is being produced with the active participation of several suppliers (Womack et al., 2004).

Accordingly, in the case of emerging markets like Brazil, technological innovations in products and processes in the automotive industry were intensified from trade liberalization in the 90s.

Carvalho (2006) points out that in this period, a decrease of the technological gap occurred in the Brazilian automotive industry from the internationalization of components, products and so called modular production systems or shared assembly.

\footnotetext{
${ }^{*}$ Corresponding author. E-mail: mdleite@gmail.com.
}

Thus, the research and development (R\&D) activities of that industry in this country have being intensified being the pioneering of ethanol engines in the 70's and now the so-called "flex-fuel cars" or dual fuel. In this regard, Consoni (2004) asserts that the initiative of the "flex-fuel" cars offered responses to local market demands and involved cooperation between automakers and suppliers operating in Brazil. Table 1 shows data on the share of gasoline vehicles and flex in Brazil from 2003 to 2008.

By involving the activities of various organizations (manufacturers and suppliers) by being a national technology and have achieved consumer acceptance, the so-called flex-fuel technology was the focus of this study. This study aimed to identify its emergence and its strategic options under the theoretical perspective of "business platform" (Gawer and Cusumano, 2002; Sugano, 2005; Boudreau, 2005; Muffatto, 1999; Seth, 2006). In this sense, the choice of biofuel technology as an object of study is justified by the fact that it occurred with the direct participation of suppliers in the development of technology (Melo, 2006; Melo et al., 2005; Teixeira, 2005). 
Table 1. Gasoline and flex-fuel vehicles share.

\begin{tabular}{ccc}
\hline Market share & Flex fuel (\%) & Gasoline (\%) \\
\hline 2003 & 4 & 89 \\
2004 & 22 & 71 \\
2005 & 50 & 43 \\
2006 & 78 & 17 \\
2007 & 86 & 10 \\
2008 & 87 & 8 \\
Acumulated 2003-2008 & 62 & 33 \\
\hline
\end{tabular}

Source: - Ministry of Development, Industry and Foreign Commerce MDIC (2009).

The conceptual perspective of "business platform" intent to demonstrate that in the current conjunction, dynamic industries may provide innovations together with its suppliers through formal skills exchanges. This way, they settle gains for the various sector organizations with a competitive and differentiated product. According to Sugano(2005), a business platform is based on complementarities between a product or a central technology, whose development entails a rearrangement of the system and other complementary products to the product or technology; In summary, this theoretical perspective could explain not only the formation of technology as the competitive potential acquired with its domain. Thus, this paper intended to show in a relational approach, as how the combination of competences between the national automotive organizations sector culminated in flex-fuel technology.

\section{Flex fuel technologies}

The flex-fuel or biofuels vehicles arise as an alternative in the global trend towards the development of a technology aimed at reducing emissions of pollutants.

Studies aimed at the use of methanol and ethanols were used as the basis for developing the concept of a Flex engine. The initial flexible management system comprises an electronic sensor in the fuel line that measures the alcohol content in gasoline. The sensor automatically adjusts the engine components to work with each mixture, the same tank, the same engine and same injection system for both fuels (Teixeira, 2005).

While the U.S. flex-fuel engines were developed from adaptations made in the gasoline engines, in Brazil it was taken the advantage of the experience with alcohol vehicles, which are equipped with a higher compression rate to get better results in terms of performance and fuel economy, besides allowing the use of up to $100 \%$ alcohol (Siqueira and Siqueira, 2004). At the beginning of the flex, there was a lot of know-how already acquired from the $100 \%$ alcohol engines. The Alcohol has a corrosion property higher than gasoline, so the injectors had to be treated, especially to resist a certain $\mathrm{pH}$ of the alcohol.

According to Figueiredo (2006), in 2002 it was announced the arrival of a product called the Power chip, which changed the programming of the electronic central of the motor, altering the characteristics of the ignition and fuel injection, to one which was also resistant to alcohol as a source of energy. Consequently, the researches were related to technical issues linked to alcohol automobiles, and their commercial prospects. In this sense, the researches' of a "flexible" engine were intended to foster the economic viability of the flex vehicle fleet, directly benefiting the end consumer and the market.

In 1998, SFS Technology - Software Flexfuel Sensor was responsible for the success of flexible-fuel vehicles in Brazil. Developed by a system vendor this technology uses a computer program (software) embedded directly into the module command of the electronic injection. In other countries, flex-fuel vehicles use a physical sensor for fuel injection which is very expensive and inconvenient to the Brazilian's standards (Teixeira, 2005). The software is sold by suppliers to automakers that manufacture equipment for electronic fuel injection.

The development of such a software for the "flex cars" started in late 1990's, with the creation of an algorithm that calculated the composition of a fuel based on information gathered by various sensors that car engines typically bring with them (Lima, 2006) .

From these data sensors the program determines the amount of fuel that is going to be injected into the motor. They received signal through a lambda probe, of the composition of gases from combustion, which allows the adjustment to be done for better engine operation. The panel memorizes the last proportion of gasoline and ethanol used in the motor and it takes charge of the cold start, when necessary (Piacente, 2006).

In this regard, the advent of electronic engine management made possible the creation of flex-fuel engine, which controls the volume of fuel injected according to the determination of a computer called the electronic control module ECM. The ECM is used to calculate the quantity of fuel to be injected with respect to stoichiometric ideal air-fuel relation (in which there is neither air shortage nor excess). The purpose of the oxygen sensor (or lambda probe) is to represent the stoichiometric ratio, $\lambda=1$ and maintain this relationship with both gasoline and alcohol. Thus, the oxygen sensor "reads" the air-fuel mixture being burned due to the greater or lesser presence of oxygen passes the information to the ECM and this provides the necessary adjustment in a few seconds (Sharp, 2008). The central idea of the sensor is based on the following reasoning: If there is more exhaustion of oxygen, the sensor reacts by burning less fuel, otherwise, if there is a smaller amount of oxygen, the sensor responds by burning more fuel.

Table 2 shows the evolution of the Volkswagen Flex Fuel engines (compared to gasoline engines) since its 
Table 2. Volksvagen flex fuel engine evolution.

\begin{tabular}{|c|c|c|c|c|c|c|}
\hline \multicolumn{7}{|c|}{ Flex fuel engine evolution } \\
\hline $1^{\mathrm{a}}$ & 2003 & $10.1-10.8$ & $\begin{array}{l}\text { 2.1\% Bigger with } \\
\text { Ethanol }\end{array}$ & $\begin{array}{l}2.1 \% \text { Bigger with } \\
\text { Ethanol }\end{array}$ & $\begin{array}{c}25-35 \% \text { Inferior with } \\
\text { Ethanol }\end{array}$ & Yes \\
\hline $2^{\mathrm{a}}$ & 2006 & $10.8-13.0$ & $\begin{array}{c}\text { 4.4\% Bigger with } \\
\text { Ethanol }\end{array}$ & $\begin{array}{c}\text { 3.2\% Bigger with } \\
\text { Ethanol }\end{array}$ & $\begin{array}{c}25-35 \% \text { Inferior with } \\
\text { Ethanol }\end{array}$ & Yes \\
\hline $3^{\mathrm{a}}$ & 2008 & $11.0-13.0$ & $\begin{array}{c}5.6 \% \text { Bigger with } \\
\text { Ethanol }\end{array}$ & $\begin{array}{c}\text { 9.3\% Bigger with } \\
\text { Ethanol }\end{array}$ & $\begin{array}{c}25-30 \% \text { Inferior with } \\
\text { Ethanol }\end{array}$ & Yes \\
\hline $4^{\mathrm{a}}$ & 2009 & $11.0-13.0$ & $\begin{array}{c}5.6 \% \text { Bigger with } \\
\text { Ethanol }\end{array}$ & $\begin{array}{c}\text { 9.3\% Bigger with } \\
\text { Ethanol }\end{array}$ & $\begin{array}{c}25-30 \% \text { Inferior with } \\
\text { Ethanol }\end{array}$ & $\begin{array}{l}\text { NO (Cold } \\
\text { Start) }\end{array}$ \\
\hline
\end{tabular}

Source; Joseph apud Yu et al. (2010:4).

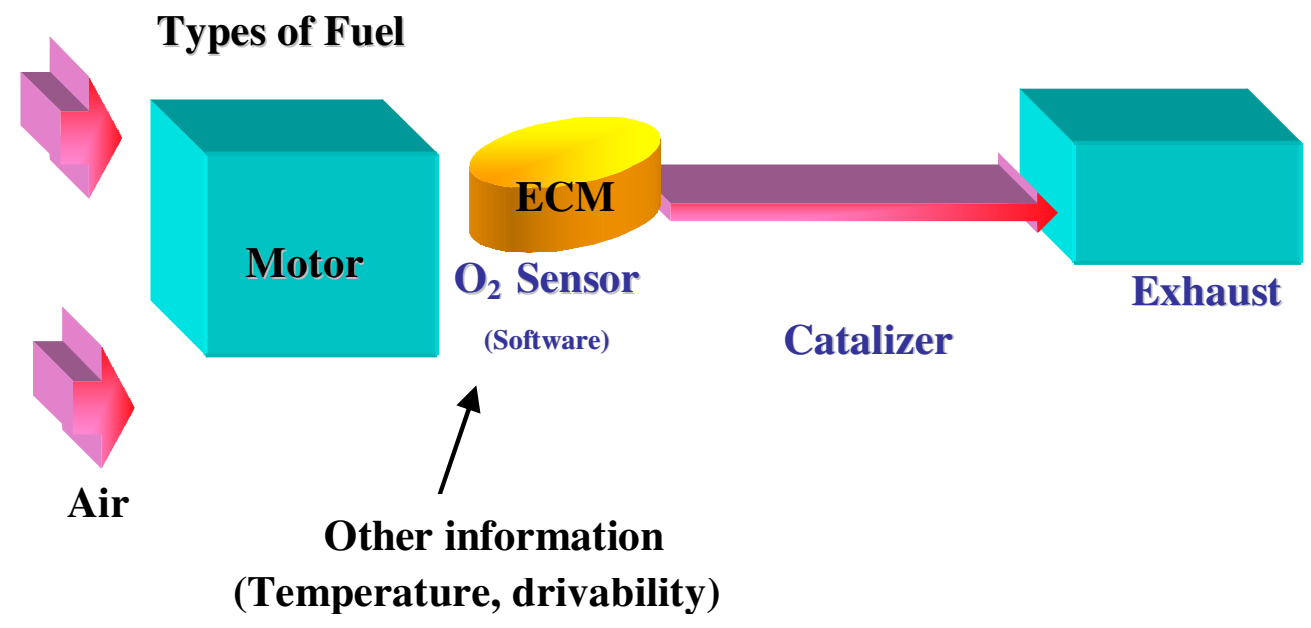

Figure 1 Flex Fuel Technology. Source: Elaborated by authors.

release in 2003.

The first generation of flex-fuel engines kept basic knowledge of engines of alcohol (ethanol) with minor power and compressions rates. The second generation of flex-fuel engines sought to provide an intermediate treatment between ethanol and gasoline. In the third generation of the engine, it reached the maximum engine compression to achieve higher torque and power respectively. Finally, in the latest generation of flex-fuel technology, a gasoline tank next to the engine was removed from the system as a result of the improvement in the so-called "cold start" of vehicles. This type of innovation brings out the possibilities of exporting flexfuel technology to other countries or to colder regions of Brazil (Yu et al., 2010). Figure 1 illustrates the Flex Fuel technology and its operation from elements of the engine:

According to Melo (2007), automotive technologies rely on expertise of firms in various areas, requiring the expertise of suppliers. Cerra (2005) supports this trend by studying automobile engines manufacturers, which ended up transferring skills to specialist suppliers. This skills transfer can be seen from the perspective of "modular organizations." As Garud and Kumaraswamy (2003) state, as firms produces goods and outsource others, it "splits" the technological system in organizations (or modules) that can create more flexible structures for the technology production by combining components.

The flex technology is based on an electronic sensor coupled to the engine and is setting a new technological standard in the automotive industry. It depended on an exchange of competencies between the organizations involved (assemblers and suppliers), generating an interdependent system of innovation or a possible "business platform" (Gawer and Cusumano 2002; Sugano 2005; Boudreau 2005 Muffatto 1999; Seth, 2006). The study with the flex-fuel engines demonstrates that any change in the subsystem of the engine causes an adjustment in the software but without the need to change it completely 


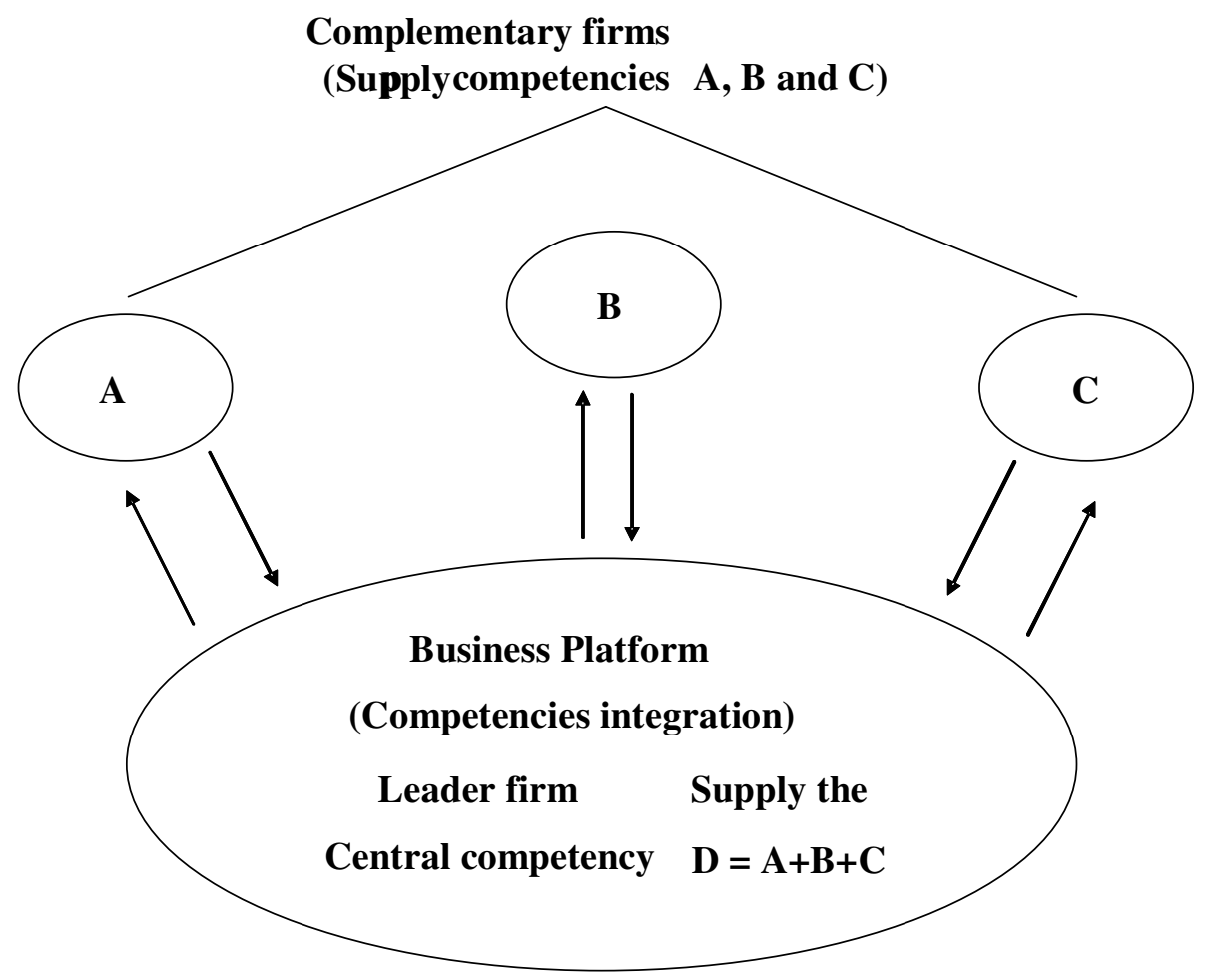

Figure 2 Business Platform Scheme. Source: Elaborated by the authors.

(Yu et al., 2010).

\section{Business platform}

The business models on platforms have become a ubiquitous feature of the information economy. Common products such as computers, cell phones, gaming systems, allow "downstream" developers to build applications that complement the core technology (Parker and Van Alstyne, 2008).

The term "platform" has become popular with executives because there is a perception that this structure can meet the needs of various organizational entities from a leadership position in an industry. These markets allow for an open interaction between diverse consumers and manufacturers. Typical examples are: Microsoft Windows and its applications developers, computer manufacturers and its users, and digital media services to its users and producers of content (Hagiu, 2006).

The idea of the strategy in "business platforms" is related to a point of view that there is a "lead organization" that produces a product that would be its core competence, and thus leads others in the industry in specific products or "complementary" services (Figure 2). According to Gawer and Cusumano (2002), a platform can be defined by a system composed of interdependent parts on which each of them separately can be innovated and in which the owner has a core technology platform. West (2003), states that the owner of a platform consist in architecture of correlated standards controlled by one or more firms.

From this perspective, the relationship between the "owner (s) of the platform and the other (s) firm(s) is modeled as monopolistic and its competitors in complementary markets. Thus, the demand in a platform depends on the demand of the whole system (companies and end users) (Gawer and Henderson, 2007).

This is therefore a concept in terms of strategy of the organizations moving towards interfirm relations in an exchange of essential skills to the formation of a product. The core competence can be defined as the ability that an organization has to transform ability into differentiated products and reach new markets. According to Prahalad and Hamel (1990), core competencies are reflected in organizational learning, through coordination and integration of various skills to produce technologies that create differentiated products. Thus, identifying what functions the company can perform with excellence functions (Project functions, production, marketing, distribution), it can compete in fields related to these functions (Contador et al., 2004).

For Boudreau (2005), a "platform" is a subset of components used and reused in a system and in multiple products such as operating systems, automotive steering and suspension. The author defines "systems" as 
manufactured products with multiple components and should work together: as computers, software and communication systems.

A business platform requires products that complement each other around a modular organizational architecture. According to Muffatto and Roveda (2000), the platforms have been more flexible modular architecture of a given business. In the case of this article, the assemblers and suppliers can be though as separate modules. It's assumed, therefore, that the modules are structurally independent units working together (Cardozo, 2005).

A platform would be then a distinct business strategy, which can be identified in a product. The notion of platform in product development allows companies to eliminate redundancies, efficiently using its resources and providing products to an expanded market. The automotive industry already uses this concept for a period of time and has achieved growing economies in the development costs, increase sales and market share (Seth, 2006).Thus, a platform can be viewed as an organizational structure, providing means of developing cross-functional teams in product development for the integration of its technical or marketing components (Muffatto, 1999).

A firm that plans to conduct a business platform must be grounded on three elements: 1) Directing the architectural innovations (product) and systemic innovations; 2) stimulate innovation in complementary firms and 3) coordinate the system (Ishii, 2006). In this regard, a "business platform" refers to a set of business capabilities that enables access to a consumer base or to a continuation of benefits for new business with advantages to the "controller of the platform" (Wonglimpiyarat, 2004).

Eisenmann et al. (2008) consider that a platform approach encompasses various types of participants, including end users, the complementary, additional platform providers that facilitate the access of technology to users. Boudreau (2008) argues that the nature of a platform gives rise to the question of what should be the degree of control in the hands of a leader firm. For the author, in a "closed system", a leading organization tends to appropriate the "platform" and leads investments in innovation for the success of the entire system in the long term. Thus, the platform can be characterized by a relation of less compatibility. A "business platform" is characterized by sets of organizational relationships between provider(s) and supplier(s) in Figure 2.

\section{METHODOLOGY}

The methodology of the present research has qualitative characteristic, an exploratory type and it aimed to understand the underpinning factors behind the so called Flex-Fuel technology, investigating the role of types of organizations involved in developing technology: automakers and suppliers.

To check the possible existence of a "Flex platform," it sought to find categories and patterns in data from the interviews, to confirm whether or not can be found the elements of a theory of "business platform flex-fuel". Thus, it was understood that this work approached the methodology based on the "grounded theory" (Strauss and Corbin 1990).The logic of grounded theory, involves the exploration of a wide variety of perspectives based on interviews for the formation of constructs and propositions (Kotabe et al., 2007).

In the approach of the grounded theory it is necessary to adopt a literature review that integrates or contrast with the generated results, and it has to be used to fill a gap, or present a new point of view of existing theory from the standpoint of view of the involved (Bandeira De Melo and Cunha, 2006).

Strauss and Corbin (1990) state that the grounded theory can be used as a theoretical reference when one want to prepare and develop an existing theory in a specific area of study. In this particular case we adopted the approach of these authors, due to the absence of empirical studies on "business platforms" as well as the attempt to expand this theoretical framework. Thus, the purpose of this work was characterized by an attempt to reach a "theoretical construction" of an innovation in the automotive sector and this research is concerned with "developing and extending a theory rather than just testing it" "(Bretherton and Chaston, 2005).

Thus, five interviews were collected using a semi-structured scheme, whose individuals (two-member from the supply companies and three members linked to the manufacturers companies) were selected according to their accessibility and by the level of knowledge about flex-fuel technology. The selected respondents had the knowledge of flex-fuel technology and even they participated on its development. The interviews were recorded and then transcribed, and it lasted for about one hour as an average.

For analyzing the interviews, it was used the method of analysis of content. Analysis of content represents techniques for communication analysis, in which, through description of the content of messages, it allows the inference of knowledge concerning the conditions of production / reception of these messages. The analysis of content focused on the categorical or thematic analysis that works by dividing the text into units (sentences, paragraphs). This choice can be justified mainly by the ease of its application in direct speech, promoting the understanding of texts (Bardin, 1979). According to Triviños (1987), by using the technique of analysis of content, several assumptions may arise as a result of the study of the communication data. For this article only the "open" categories approach on the "business platform" was analyzed.

\section{RESULTS AND DISCUSSION}

\section{The flex-fuel technology as a "business platform": Changes in engine architecture}

The architecture of a product can be defined more precisely as: the grouping of its functional elements, the mapping from functional elements to physical components and the specification of the interfaces that makes possible the interaction between the physical components of the product. In this sense, the architecture of a product can be integral in the sense that all components are tightly integrated as the case of an automobile. A subtle change in functionality requires modification on several other components, which requires strong coordination of tasks for the assembly (Ulrich, 1995). The vehicles have more global features than, for example, the PCs, and therefore, it needs to be built on an integral architecture that makes more difficult to proceed major changes (Fixson and Sako, 2001). 
In this regard, considering the engine as a platform, its development accounts for about $80 \%$ of the total development cost of the vehicle, besides the production of modules happen to be very expensive. Therefore, the modularization becomes unfeasible instead of an integral architecture (Muffatto, 1999). The development of the flex-fuel reflected in a few minor changes in the overall architecture of an automobile, as shown in the passages (01) and (02) which represent the respondents of an automaker and a supplier of flex-fuel system, respectively:

(01) "Subtanks, pump, solenoid valves, the injection nozzles ... In this (engine) the (change) was big ...is the spark plug, the piston rings. The valve changed ...that really was an inner change...a control of 51 pieces in a universe of nearly $500 \ldots 10 \%$...Seems unlikely, but it is enough ".

(02) The "flex-fuel is a system that works with the following elements: pump, tubes, canisters, which may be different for each automaker. The compression rate (ratio of air and fuel) of the system is intermediary $(12: 1)$ the rate of methanol cars (14:1) and gasoline (11:1) ".

From the point of view of one of the suppliers of flex-fuel technology, there were also changes in the engine architecture that provided market return. Gawer (2000) states that architecture plays a key role in product demand on a platform.

(03) "It's to adapt the compression ratio of the engine, adjust the engine's combustion chamber, because it is trivial, then the combustion done with alcohol, the combustion made from gasoline, a combustion with a mixture is different" that was done. "

(04) "The market result, which gave the result was so impressive that no one had any doubts that this was the solution, that it was the future that everybody had to get involved with in that product, in that product we will say so"

\section{The Flex-Fuel technology as a "business platform": The relationship of systems with the automakers: The partnership}

Innovations like the flex-fuel system has been developed and supplied to the automakers as a complete module. In this study, we asked to both, supplier and automakers, how this technological development was achieved through the association among them.

In the specific case of flex-fuel technology, the supplier organizations (systemist) have chosen the development of electronic fuel injection systems as a focus of their competence. However, the competence to integrate different electronic and mechanical systems, creating products with valuable features and specifications for end customers is still exclusive of the manufacturers (Mello et al., 2005).

According to Mello et al. (2006), since the innovation of dual fuel engine involves the modification of various components it becomes difficult to delegate it only to suppliers for the engine to be functional. Therefore, the development of electronic systems has become an activity in which the automaker would not be able to compete without specialized suppliers, according to a member of a searched automaker.

(05) "See, some specifications of the engine they are our responsibility, because the Knowhow is inside here, then, for example, when we speak to define certain components, material used, the engine when you talk a lot about the compression issue, the compression rate is one of our responsibilities, meaning, the know-how to set the compression ratio is inside of who makes the engine "...

(06) "There are also situations where the knowhow of the component is there on the supplier side. An example is the injection nozzle, this is a component that who manufactures it, is a supplier, then he is who really has the knowhow, then we started working together because we have the engine that has certain performance characteristics and he has the injector nozzle, so we already start to converge and then set the injection nozzle according to the needs of the engine....

This "partnership" called co-design is confirmed in the excerpts below, by the respondents from an automaker and a supplier of flex-fuel system respectively:

(07) "This proximity exist, that strong bond with the supplier, because the suppliers are strong, they have the technology, are competitive and are our partners today, then this channel is now a very active channel and in both directions, right,? Being us asking them: Look I would like to improve a product or a Flex, its, about it and even suggests how to deploy enhancements and vice versa. In the same way if they see opportunities to develop a component or any concept to improve the technology, the channel is very open, very proximal. "

(08) "The partnership is born where our engineers share the activities, the testing, the developments with the assembler, discuss ... The improvement process born, a chain actually 
born and a great partnership between the automaker and supplier, is a, partner, is a codesign is called "...

In terms of the business platform approach, it can be said that related to the engines there is an exchange of expertise between these suppliers. In some cases, suppliers also need to provide not only the components themselves, but an "extra" or complementary products that are required for the core products and thus there is a relationship of interdependence between firms producing the central product and its suppliers (Gawer and Cusumano, 2002). Thus, alliances are an effective mechanism for combining complementary assets with skills, essential to obtain synergistic gains (Colombo et al., 2006). These factors are confirmed by the respondents of the automaker and a supplier organization, respectively:

(09) "Nothing happens, let's say it that way, in a isolated manner or lets say it in a imposed way, in reality, the partners must come together each one with their competence to arrive later in to the final product..."

(10) "The partnership means that every one on its side puts their knowledge, skills, to make a" package "...Then comes the partnership, there is developed a partnership ...the (company) "sits" with all manufacturers ...there is a very open partnership, very positive in the sense of opening the game up to see where the game is and also from another side to open the game, to see very clear..."

\section{The flex-fuel technology as a "business platform": the power of the automakers in the "architecture" platform: the standardization of components}

According to Venanzi (2000), changes in the strategies of automakers have been created from relations between these companies and their suppliers. In this sense, these changes were reflected in the definition of a hierarchy in the supply chain, and reduction in the number of suppliers to automakers. Thus, the relations between the automakers and large suppliers (systemists), there is a market that converges to the co-design or co-project with large suppliers (Quintão, 2003).

According to Cardoso (2006), the relationship between suppliers has several variations in levels of the chain, depending on the size of the supplier. Thus, some companies in Brazil have adopted the policy of transacting with a supplier, while others have adopted more than one to strengthen their bargaining power through four key factors: Quality, commitment to the new delivery system, resources engineering, and price (Humphrey and Salerno, 1999). These factors are confirmed as follows by respondents in two surveyed automakers:
(11) "Look, our company's policy is to work with more than one partner and there will have several aspects, right? The commercial, technological, strategic aspects, of you having more than one supplier, then this are the politics, it was when we started in early 2000 to develop Flex and today we have three suppliers and we have three as partners. .. the cost is an important issue and these three suppliers are extremely competitive, today they are in the market and are providing to us because they are competitive, besides that they have another very strong point, all three have a engineering structure here in Brazil, which fully meets our needs, that is very important"...

(12) "The (automaker) began to develop the Flex project, it called several suppliers, examined each proposal, each technological option of suppliers here in Brazil. Among several suppliers exist one that is more aligned with the philosophy of the (automaker). The (automaker) don't care about cost only, it is clear that the cost is fundamental for one who wants to survive in the market, but the issue of quality is even more important when it involves engines right? The engine is the heart of the car ...It also does not seek to change much the supply, because that question about development of the mentality of the supplier, and it is important to the automaker".

Cerra et al. (2007), claim that vendors are generally dependent on the strategies of automakers, and accept the requirements regarding to technical specifications and quality of supplied products. This reality makes the flex-fuel technology to be "standardized" by automakers and consequently acquired from different suppliers, as can be seen from the excerpts below from both, the interviews of a supplying organization the flex-fuel technology and from an automaker, respectively:

(13) "The Flex system was originally sold "closed" to the automakers, which were setting it up in the vehicles. Currently, automakers can coordinate the chain, and establish specific standards for vehicles in terms of features ... "Automakers can acquire technology from any supplier that offers more advantages in price, or meet the automakers specifications. In this sense suppliers want to differentiate its components, while automakers seek standardization. Usually the final client of the systemist is the automaker ..."

(14) "The automaker is looking for the cost reduction, but oppositely the supplier has the mechanism to protect himself and I know that in 


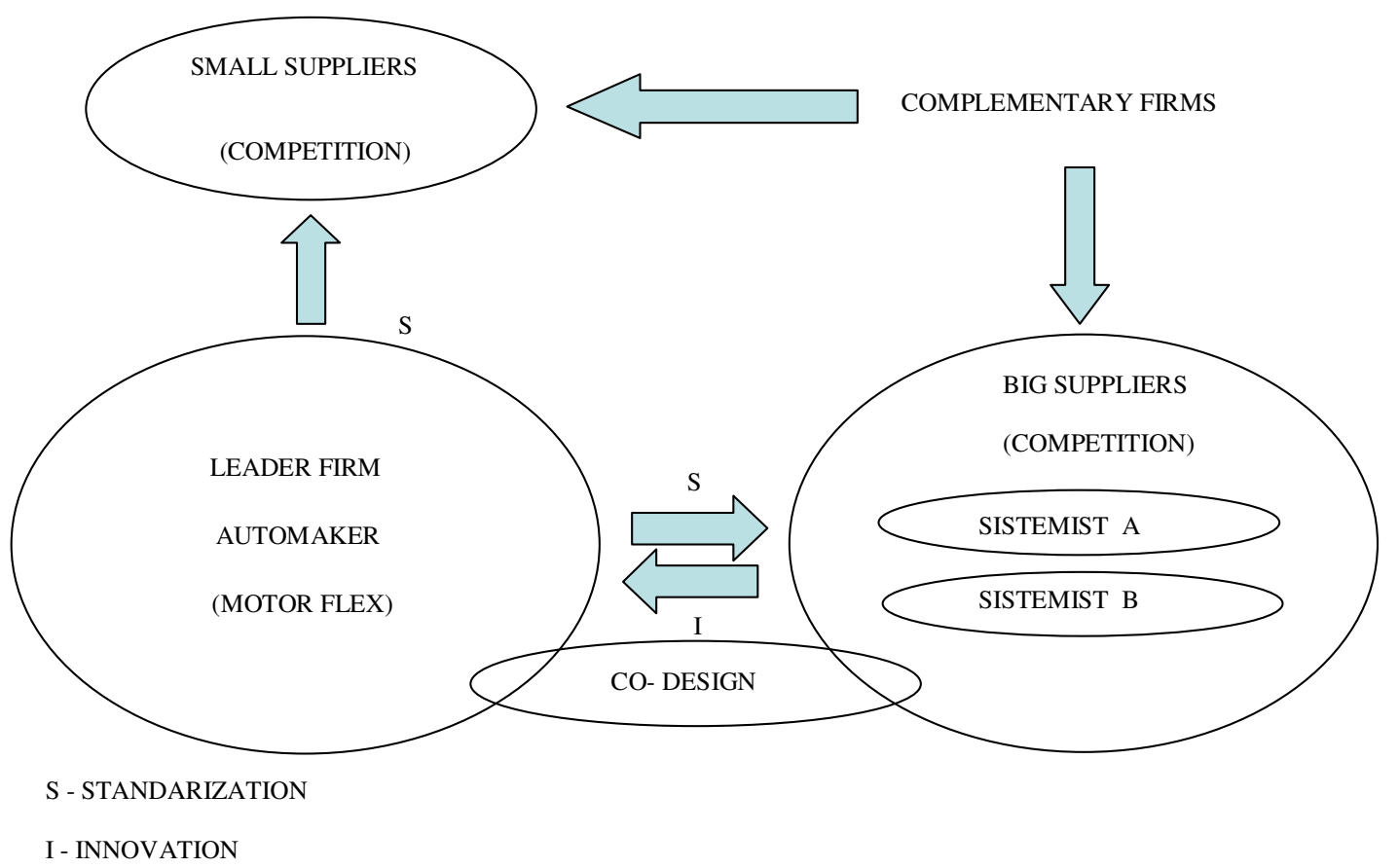

Figure 3. The model of the "business Flex-Fuel platform" Source: Elaborated by the authors from the interviews.

the case of ( $x$ assembler) they have a policy like that: they develop two, three suppliers to the same automobile part. Due to the volume they have, and then they have two or three options. So what happens if a supplier ...is not capable to supply, they say: no, my price is $X$ and I have another that is $10 \%$ less... It generates a competition between these suppliers"

Gawer and Cusumano (2002), affirm that the strategy in a context of platform, has an "architect" capable of integrating all the skills for a core technology, One final issue refers to the standardization of the subcontractors (suppliers of the "major suppliers"), according to the excerpts of the interview in one of the surveyed manufacturers:

(15) "Depending on the supplier, if the automaker feels that the primary supplier is not succeeding in developing the secondary, it comes too ..."

Finally, the present study conclude that, considering the architecture of the product (engine) as technology (core competency), there is the lead of automakers in the conduction and management of the "flex-fuel" platform which requires the existence of "complementary suppliers" of electronic systems that compete for innovations. All these elements are associated with flex-fuel technology as a creator of value and its diffusion through the market was through the interaction of competence (in this case through the co-design) between the automakers and large suppliers (systemists), while addressing the related business platforms, as shown in Figure 3.

\section{Conclusion}

The development of flex-fuel technology was studied according to the approach of "business platforms" in which technologies are best created and disseminated through exchanges of expertise between organizations (modules). In this paper, we considered the automakers and suppliers as separate modules that finally must work together.

The "business platforms" are composed of an organization that provides the "core technology" and from other organizations which manufacture complementary products to that technology. This system must operate in an interdependent way, coordinated by an organization that provides an environment for stimulating joint innovation.

The flex-fuel platform is led by automakers that have as a central rule in the architecture of the engine.

Innovations of high aggregated value, as was demonstrated here through the case of flex-fuel engine, require partnerships of the "complementary" technology suppliers with the automakers. The flex-fuel platform has the engine as the central piece. It makes the standardization of components a very important issue for the development of flex-fuel because it does not allow the differentiation strategy from the supply side, both for the 
large companies, and also for small suppliers.

The power of the automakers in the "architecture" of flex-fuel platform was highlighted by leadership positions in the automotive chain, making possible the "standardization" of components. Note that the implications of this process can be seen in two levels of suppliers: 1) In the first tier, the so-called "systemists", who are responsible for the delivering of complete systems to automakers (modules); with structure and technological level required by automakers, and 2) In the second tier which encompasses all the producers of parts and simpler components supplied for the "systemists".

When the maker of appropriates technologies might require quality and price conditions, it was verified that only one engine was the capable element of directing the innovations, generating competition and adequacy of other firms or "business flex-fuel platform". Given these characteristics "business flex-fuel platform" can be considered a closed system in which the automaker appropriates the profits of the supplier.

\section{REFERENCES}

Bandeira-de-Mello R, Cunha CJC de A (2006). Grounded theory. (Eds): Godoi CK, Bandeira-de-Mello R, Silva AB. In: Qualitative Research in organizational Studies: paradigms, strategies and methods. São Paulo: Saraiva. 241-258.

Bardin L (1979). Content Analysis. Lisboa: Eds 70.

Boudreau K (2008). Opening the platform vs. opening the complementary good? The effect on product innovation in handheld computing. HEC Working Paper. http://ssrn.com/abstract=1251167 [mar 04. 2008]

Boudreau K (2005). The boundaries of the platform: vertical integration and economic incentives in mobile computing. MIT - Sloan School of Management. Working Paper. Cambridge, MA, http://ssrn.com/abstract=834984 . [mar. 04. 2008].

Brazilian Ministry of development industry and foreign commerce MDIC (2009). ethanol http://www.mdic.gov.br/sitio/interna/interna.php?area=2\&menu=999 [05 nov 2008].

Bretherton P, Chaston I (2005). Resource dependency and SME strategy: an empirical study. J. Small Bus. Enterprise Dev., 12(2): 274-289.

Cardoso AM (2006). The new face of automotive industry or the convergence thesis revisited. (Eds): Cardoso A, Covarrubias A. In: automotive industry in Americas: the strategic and social reconfiguration of productive actors Belo Horizonte: UFMG/IUPERJ. 79-112.

Cardozo MA (2005). Modularization and design: A case Study on Cockpit's of Fox model at Volkswagen of Brazil Masters Dissertation Federal University of Paraná, UFPR Curitiba.

Carvalho RQ (2006). Interfirm relations, governance and technological development in Brazilian's Automotive chain (Eds): Cardoso A, Covarrubias A. In: automotive industry in Americas: the strategic and social reconfiguration of productive actors. Belo Horizonte: UFMG/IUPERJ. pp. 63-78.

Cerra AL (2005). Technological Strategies in Supply Chains from the Brazilian Automotive Industry: Case Studies in Companies from the Automotive Engine Segment. Doctorate Thesis, Federal University of São Carlos, UFSCAR São Carlos.

Cerra AL, Maia JL, Alves FAG (2007). Strategic, structural and relational aspects of three automotive supply chains. Revista Gestão e Produção, São Carlos, 14(2): 253-265.

Colombo MG, Grilli L, Piva E (2006). In search of complementary assets: The determinants of alliance formation of high-tech start-ups. Res. Pol., 35(8): 1166-1199.
Consoni FL (2004). From "Tropicalization" to car project a study of competences in product development on the automakers in Brazil Doctorate Thesis Geosciences Institute. University of Campinas,UNICAMP Campinas.

Contador JL, Ryllo EF, Contador JC (2004). Determination of the Core Business da company. National Association of Graduate Studies and Research in Administration ANPAD, Curitiba, PR Brazil 28.

Eisenmann T, Parker GV, Alstyne M (2008). Opening platforms: how, when and why? Harvard Business School. Working Paper. http://hbswk.hbs.edu/faculty/teisenmann.html [feb 03 2009].

Figueiredo SF de (2006). The ethanol car: an experience of public policy for innovation in Brazil . Masters Dissertation - Sustainable Development Center. University of Brasília, Brasília.

Fixson S, Sako M (2001). Modularity in product architecture: will the auto industry follow the computer industry? An analysis of product architecture, market conditions and industrial forces. IMVP/ MIT Working Paper. Cambridge, MA, http://imvp.mit.edu/pubarcindx.html [feb 03 2009].

Gawer A, Cusumano MA (2002). Platform leadership: how Intel, Microsoft, and Cisco Drive Industry Innovation. Boston: Harvard Business School.

Gawer A, Henderson R (2007). Platform owner entry and innovation in complementary markets: Evidence from Intel. J. Econ. Manage. Strat., 16(1): 1-34.

Gawer A (2000). The organization of platform leadership: an empirical investigation of Intel's management processes aimed at fostering complementary innovation by third parties. Ph.D Thesis-. Massachusetts Institute of Technology, Cambridge, MA.

Garud R, Kumaraswamy A (2003). Technological and organizational designs for realizing economies of substitution. (Eds): Langlois RN Garud R, Kumaraswamy A. In: Managing in the modular age: architectures, networks, and organizations. United Kingdom: Blackwell. pp. 45-68.

Hagiu A (2006) Multi-sided platforms: from microfoundations to design and expansion strategies. Harvard Business School. Working Paper. http://hbswk.hbs.edu/faculty/ahagiu.html [feb 03 2009].

Humphrey J, Salerno MS (1999). Globalisation and assembler-supplier relations: Brazil And India. Actes du Gerpisa. http://www.gerpisa.univ-evry.fr/ancien-gerpisa/actes/25/index.html [Dec 12 2008].

Ishii M (2006). A strategic method to establish sustainable platform business for next generation home network environments. Masters Dissertation - Massachusetts Institute of Technology, Cambridge, MA.

Kotabe M, Parente R, Murray JY (2007). Antecedents and outcomes of modular production in the Brazilian automobile industry: a grounded theory approach. J. Int. Bus. Stud., 38(1): 84-106.

Lima J. G de (Fevereiro 2006) the Wealth is the knowledge. Revista Veja. Ed 1941. http://veja.abril.com.br/acervodigital [sept. 04 2008].

Melo AA de (2007). Proposal of a structure for analysis and Classification of the relations between suppliers- costumers, National Association of Graduate Studies and Research in Administration 31, Brazil Rio de Janeiro, RJ.

Mello AM de (2006). Innovative Capacity Maintenance by Automakers in a Product Development Outsourcing Scenario - The case of Brazilian Automotive Industry Masters Dissertation University of São Paulo, USP São Paulo.

Mello AM de, Vasconcellos LHR, Marx R (2006b). The Outsourcer's initiative. HSM Management Update (36).

Mello AM de, Vasconcellos LHR, Marx R (2005). Would the automakers giving up of their core competences on the engines development? A Case Study of national first biofuel car. National Association of Graduate Studies and Research in Administration ANPAD 29, Brazil Brasília DF.

Muffatto M (1999). Platform strategies in international new product development. Int. J. Oper. Prod. Manag., 19(5/6): 449-459

Muffatto M, Roveda M (2000). Developing product platforms: analysis of the development process. Technovation, 20(11): 617-630.

Parker G, Van Alstyne M (2008). Innovation, openness, and platform control. Harvard Business School. Working Paper http://ssrn.com/abstract=1079712 [feb 03 2009].

Piacente EA (2006). Brazilian perspectives in the international market of 
ethanol. Masters Dissertation University of Campinas,- UNICAMP Campinas.

Prahalad CK, Hamel G (1990). The core competence of the corporation. Harv. Bus. Rev., 68(3): 79-91.

Quintão RAC (2003). Coordination and technological improvement in the Brazilian automotive chain: the reflections for small and médium auto-parts producers. Masters Dissertation University of CampinasUNICAMP Campinas.

Seth D (2006). A platform based approach for embedded systems software development. Thesis Massachusetts Institute of Technology, Cambridge, MA.

Sharp B (2008). "How stuff works - How Flex Engine Works ".http://carros.hsw.uol.com.br/motor-flex1.htm [03 sep 2008].

Siqueira DA, Siqueira AA (2004). Study and evaluation of Flex Fuel. Technology Rio de Janeiro: IPRJ-UERJ,. http://www.abcm.org.br/xi_creem/resumos/AA/CRE04-AA04.pdf [03 sep 2008].

Strauss A, Corbin J (1990). Basics of qualitative research. London: Sage.

Sugano JY (2005). The Structure of Web Platform Strategy: Mapping Organizational Interrelationships trough an Exploratory Analysis of the Internet-Based Companies. PHD thesis Osaka: Osaka University.

Teixeira EC (2005). The development of Flex Fuel. Technology in Brazil São Paulo: DNA Brazil Institute, 28 p.

Triviños ANS (1987). Introduction to research in social sciences: Qualitative research in education São Paulo: Atlas.
Ulrich KT (1995). The role of product architecture in the manufacturing firm'. Res. Pol., 24, 419-40

Venanzi D (2000). Analysis of gains of the new configurations in the auttomotive industry and supply chain management. Masters Dissertation, University Center of Sant'anna, São Paulo.

Vergara SC (2006). Research Methods in Administration. 2nd Ed. São Paulo: Atlas.

Vieira CR de B (2001). Fully integrated chain in automotive industry: an analysis of supplying demands in auto-parts companies of the Rio Grande Do Sul. Masters Dissertation, Federal University of Rio Grande Do Sul UFRGS, Porto Alegre.

Yu ASO, Nascimento PT de, Silva LLC da, Júnior ASC, Duranti CM, Moura CB (2010). Evolution of flex-fuel technology: a case study on Volkswagen Brazil., National Association of Graduate Studies and Research in Administration-ANPAD 34, Brazil Rio de Janeiro, RJ.

West J (2003). 'How Open Is Open Enough? Melding Proprietary and Open Source Platform Strategies'. Res. Pol., 32(7): 1259-1285

Womack JP, Jones DT, Roos D (2004). The machine that changed the world. 4. Ed. Rio De Janeiro: Campus.

Wonglimpiyarat $J$ (2004). The Use of Strategies in Managing Technological Innovation. Eur. J. Innov. Manage., 7(3): 229-250. 